\title{
POLITICAL AND ECONOMIC RELATIONS OF STRATEGIC TRIANGLE AMONG CHINA, TAIWAN AND UNITED STATES (1996-2016)
}

\author{
Pedro Pietrafesa ${ }^{1}$, Amélia Gonçalves da Silva ${ }^{1}$ \\ 1- Pontifícia Universidade Católica de Goiás, Goiânia, 74175-120, Brazil. \\ * pedro.pietrafesa@gmail.com
}

Submitted: 14/11/2019. Accepted: 26/11/2019

Published: 28/11/2019

\begin{abstract}
Purpose: The paper aims to analyze the political and economic relations between China and Taiwan from 1996 and 2016.

Methodology/Approach: Multi-method methodology is applied to understand 20 years of complex interdependency relation between China and Taiwan. A logistic regression model is used to stablish the interactions among the variables and then a historical perspective provides an in-depth discussion regarding the political entities' relationship.

The findings: China as the principal Taiwanese trade partner provokes a dilemma to Taiwan, because these condition pressure to Taiwanese government adopt international insertion that don't compromise the Chinese preferences. Also, China hostile diplomacy, situation in strategic triangle among China, Taiwan and United States, and electoral period correspond the other variables that influences Taiwanese political behavior.
\end{abstract}

Research Limitation/implication: The analyses don't cover the Tsai Ing-wen government but indicates the possibilities to the current administration.

Originality/Value of paper: Although the paper has a historical limitation, the originality is the use of multi-method approach. This paper contributes in methodological and theorical assessment about economic and political relations between China and Taiwan.

KEYWORD: trade development, strategic triangle, China, United States, Taiwan.

\section{RELAÇÕES POLÍTICAS E ECONÔMICAS DO TRIÂNGULO ESTRATÉGICO ENTRE CHINA, TAIWAN E ESTADOS UNIDOS (1996-2016)}

\section{RESUMO}

Proposito: O artigo tem como objetivo analisar as relações políticas e econômicas entre China e Taiwan entre 1996 e 2016.

Metodologia: Método multi-método é aplicado para entender os 20 anos de complexa relação de interdependência entre China e Taiwan. Um modelo de regressão logística é usado para estabelecer as interações entre as variáveis e, em seguida, uma perspectiva histórica fornece uma discussão aprofundada sobre o relacionamento das entidades políticas. Resultados/Achados: A China como principal parceiro comercial de Taiwan provoca um dilema para Taiwan, porque essas condições pressionam o governo de Taiwan a adotar uma inserção internacional que não comprometa as preferências chinesas. Além disso, a diplomacia hostil da China, a situação no triângulo estratégico entre China, Taiwan e Estados Unidos e o período eleitoral correspondem às outras variáveis que influenciam o comportamento político de Taiwan.

Limitação da pesquisa: As análises não cobrem o governo de Tsai Ing-wen, mas indicam as possibilidades para o atual governo.

Originalidade: Embora o artigo tenha uma limitação histórica, a originalidade corresponde ao uso da abordagem multi-método. Portanto, contribui na avaliação metodológica e teórica sobre as relações econômicas e políticas entre China e Taiwan.

PALAVRAS CHAVE: desenvolvimento comercial, triângulo estratégico, China, Estados Unidos, Taiwan. 


\section{INTRODUCTION}

The aim of the paper is to analyze the political and economic relation between China and Taiwan, from 1996 to 2016, its impacts on Taiwan's economy and how influenced the Taiwanese international insertion. The Taiwan perspective of theses relations are the focus of the analyses. During the eight years of Ma Ying-jeou's administration he established an economic and political approximation with the People's Republic of China. Some agreements were signed between China and Taiwan (SEF, online). Despite the agreements signed by the two side of the strait, there are internal questionings, in Taiwan, about the effectiveness of the cross-strait policy not only to Taiwan economy, but also to its international affairs (CABESTAN, 2013). The elections of Tsai Ing-wen on January 2016 changed the directions of Taiwanese foreign relations regarding China. The inaugural speech made on $20^{\text {th }}$ May 2016 was an indication that changes are coming.

A central Ma Ying-jeou administration's foreign politics was the improvement on the relations with China. The principles of Ma's cross-strait policy, declared during 2008 presidential campaign, were: no unification, no use of force, mutual non-denial, and easy issues at first then difficult ones (DUCHÂTEL, 2010). Consequently, the economic and financial spheres were prioritized in the bilateral relationship. The accelerated integration of both economies turns the People's Republic of China a key factor for the Taiwanese economy.

On the other hand, political/security talks were unlikely to go somewhere. On 2009 , for instance, Beijing tried to push for political talks and Taipei refuse to go further, the main argument was that no consensus in Taiwan society about peace agreement, or even, a reunification process (ZHANG, 2013). The new president, Tsai Ing-wen, classified the Ma Ying-jeou's cross-strait policy as reckless, because of its extreme economic dependence on Mainland China. The core inquire is whether the Taiwan economic growth should be overdependence on People's Republic of China (HUANG, 2014).

The Ma administration brought a scenario of tranquility into Taiwan Strait, different from more conflict period during the second government of Lee Teng-hui, and the presidency of Chen Shui-bian (CLARK, 2011). The election of Tsai Ing-wen brings the question, what causes changes in Taiwanese Cross-Strait Policy?

The concept of a "strategic triangle" is useful in an analysis of the relationship between countries. The preconditions for a triangular relationship recognize the strategic salience and distinct pattern dynamics, consisting of mutual relationships among all (Dittmer, 1981; Szabo, 2018; Wu et al., 2018; Steff and Dodd-Parr, 2019). The Analysis of the possible changes or stabilities of the foreign policy covered by Hasegawa (2018), Dreyer (2019) and Yang \& Chang (2019) and other researchers is an important area of International and Economics studies. In this regard, the research will respond the following questions: How depth is the Mainland China and Taiwan economic integration? There is space for great changes on the cross-strait policy after the January 2016 presidential elections?

The research is centered on a case study. The method allows the connection among the possible causes to observable results. The focus is on sequential process of specific historic case. The method requires the transformation of the pure narrative of social, economic and political facts on analytical explanations based on theoretical variables. The research exams officials' archives, surveys, interviews, among other sources, to establish consistent explanations with the unbroken chain of evidences to observe certain results (GEORGE and BENNETT, 2005).

The paper is divided in three sections. The first section discusses the material and methods used in the paper. The second section debate the regressions results applied to test the Chinese interference in Taiwanese policy. The third and last, section the conclusion.

\section{MATERIALS AND METHODS}

To analyze the multiple causal impacts on the Taiwanese Strait policy from 1996 to 2016, the present work investigates how the international and the domestic context shaped the Cross Strait Foreign Policy of the last five presidential administrations is relevant observes the feedback effects of previous Cross-Strait relations on the identities and interests of Taiwanese currently government. 
The historical analyses are important not only to know the differences among the foreign policies, but also to understand, specifically, the Democratic Progressive Party (DPP) learning on how to deal with China. The redefinition of goals and change in identity are part of learning process. Combine to the historical approach the paper will apply a statistics analysis. So, there is a multimethod base to understand the China and Taiwan political and economic relations.

The logistic regression model was chosen to analyze how the explanatory variables of the study influence the diplomatic action adopted by Taiwan. All explanatory variables were included in the initial model, except for the US diplomatic action, because the chi-square and Kruskal-Wallis tests indicates that the relation between the variables US diplomacy and Taiwanese foreign actions was not significant. In the next section, the discussion and results of regression model are expose.

The dependent variable is the Taiwanese diplomacy actions regarding China. The variable shows the Taiwanese cooperative or conflictive posture ordered in three different scales, the gradations are: cooperative, hostile and neutral. The actions were collected from Mainland Affairs Council (MAC) and Center for Strategic and International Studies (CSIS) database, daily CrossStrait activities were available, the paper aggregate the diplomatic actions per month, totalizing 240 observations.

The independent variables are divided in three dimensions: international context; domestic politics; and economy. The first dimension analyzes the Chinese and the American diplomatic actions regarding Cross-Strait relations and the Strategic Triangle developed among the three governments (United States, China and Taiwan). The Chinese diplomatic activities are considered the most important variable to understand the Taiwanese cooperative or conflictive actions during the period of analyses. After China rejoined Hong Kong and Macau into its territory, the unification with Taiwan becomes top priority on Chinese foreign policy. The China diplomacy declared in different moments that the Taiwan issue will not be unresolved indefinitely (LIN, 2016). The Chinese Strait Actions will be a categorical variable ordered as cooperative, hostile and neutral.

Another international actor we are going to is the American movements towards the Taiwan Strait. According to Christensen (2006), the Taiwan is the more sensible issue into the SinoAmerican relations. The United States provide military protection to Taiwan since the end of civil war in 1949, not allowing Mainland China uses its military superiority to unify the territory by the use of force (WU, 2005). The U.S. Department of State web site demonstrates that the United States has a legal commitment to aid Taiwan in its defense capabilities. Although, this doesn't mean the U.S. government will support every Taiwanese action regards Cross-Strait relations, if Taiwan government tries to change the status quo unilaterally, as happened during Chen Administration, the White House probably will not support Taiwan position. The American presidents have a realist knowledge about the relation with China, recognizing the Chinese importance growth in the international system and pursuing for more cooperation than conflict with China in global and regional issues, the realpolitik prevails in this relation (WEI, 2004). The paper categorizes the variable values as cooperative to China, cooperative to Taiwan.

The last variable of international dimension is the asymmetric power. The paper incorporates this variable because it is a characteristic in the Taiwan Strait relationship. (WU, 2012). In the asymmetry theory, according to Wormack and Wu (2010), the weaker side is not able to confront the capacities of the stronger side. However, the stronger side cannot impose, in a sustainable way, it will over the weaker. This occurs because the asymmetric relation is not characterized by domination and obedience, the bases for negotiations and interactions not only are the acknowledge by the stronger side of the weaker autonomy, but also the acceptance of the weaker side of its limits and opportunities in the relationship.

Since the end of the Chinese Civil War, in 1949, a Strategic Triangle relation was conformed in the Taiwan Strait. Washington, Beijing and Taipei are the components of this triangle. From the 1950 to the 1990, Beijing and Taipei struggled for the legal sovereignty of China, which included the territory of Taiwan and Mainland. In the beginning of the 1990's, Taiwan recognized the People's Republic of China as political entity. The puzzle emerging from the 1990 decade is the international status of Taiwan, if it is part of China or a separate country with its own sovereignty. 
In addition, there is the United States, which plays a role to balance the rivalry between China and Taiwan since 1949 (BUZAN and WAEVER, 2003; CLARK, 2011). The work assumed that in the real-world superpower, as United States, rising power, as China, and mini states, as Taiwan are not in the same category of influence in the foreign affairs (WU, 2011). To measure the Strategic Triangle in our model we used the index elaborated by Wu (2011) to calculate the weight of a nation inside the Strategic Triangle. The index is derived from it capabilities, military and economic, plus the interaction with the others players. Data was collected regarding the GDP from the International Monetary Fund, and information about military expenditure from Stockholm International Peace Research Institute.

The second dimension is the domestic politics. The domestic context in Taiwan is also important to understand and explain the changes and stabilities in the China and Taiwan relations. Election period, political party in power, government acknowledge of 1992 consensus and public opinion regard independence, status quo or unification are the variable introduced in our model. The first three domestic variable are binary and the public opinion continuous.

The third dimension is the economy. In Cross-Strait relations after the democratization process there is a trend that correspond the increase of economic exchange. The end of three no's policy - no contact, no negotiation, and no compromise with the communist party -, China becomes the biggest economic partner of Taiwan since 2005. The intensity of economics ties may promote the rise of political costs to Taiwanese new governments that wants to change the Taiwan interdependence to Chinese market, this correspond another pressure element of CCP against Taiwan. This variable is measure by the percentage per month of the trade exchange between China and Taiwan. Besides the trade amid the two side of the Strait, the Taiwanese economic growth was incorporate into the model because the economic tie with China is an important factor of Taiwanese GDP.

\section{RESULTS AND DISCUSSION}

As shown before, during the initial procedures of modeling the US diplomatic actions are less likely to have a big influence on the Taiwanese China Policy during the period of 1996 to 2016. The history demonstrates that the Taiwanese Diplomacy counts on the American military support to handle the Chinese threaten. As we discussed before the Americans military aid to Taiwan is an element that prevails the Chinese use of force against Taiwan to reach unification. The role played by Washington changed through the years. Until the 1970's, U.S. form an official alliance with Taiwan against China, in 1979 the U.S. government switch the diplomatic recognition to Beijing and establish an informal cooperation with Taipei, this framework provided a fairly amicable relations among the three during the 1980's. After the Cold War, the relations among the three actors become more instable and complex, varying on specific actions of each side (CLARK, 2011). Washington has been the guarantor of Taiwan security, and the major obstacle to Beijing achieves Cross-Strait reunification, especially, by the use of force (DITTMER, 2011; WORMACK and WU, 2010). In general, since the Three Communiqués (1972, 1979 and 1982) and the Taiwan Relations act (1979), the United States policy is concerning the stability through the Taiwan Strait, if China would reunified Taiwan into it territory, or Taiwan become independent, must be achieve by a pacific way (BULLARD, 2008). The new American Asia Policy may change the scenario.

As three continuous variables were added to the model, the linear correlation between them was analyzed in order to evaluate possible problems in model estimation. As seen in Table 1, the weak linear correlation presented indicates no multicollinearity between continuous variables.

Table 1: Correlation Matrix for Taiwan's Economic Growth, China's Participation in Taiwan's Foreign Trade, and Taiwan's Situation in the Triangle

\begin{tabular}{l|c|c|c}
\hline \multicolumn{1}{c|}{ Variables } & $\begin{array}{c}\text { Taiwan's } \\
\text { Economic Growth }\end{array}$ & $\begin{array}{c}\text { China's Participation in } \\
\text { Taiwan's Foreign Trade }\end{array}$ & $\begin{array}{c}\text { Taiwan's Situation } \\
\text { in the Triangle }\end{array}$ \\
\hline Taiwan Economic Growth & 1,0 & $-0,228$ & $-0,248$ \\
\hline China's Participation in Taiwan Foreign Trade & $-0,228$ & 1,0 & 0,054 \\
\hline Taiwan's Situation in the Triangle & $-0,248$ & 0,054 & 1,0 \\
\hline
\end{tabular}

Source: Elaborated by the author. 
The table 2 presents the estimates for the initial dichotomous logistic model in which Taiwan's cooperative diplomatic action is the category of the response variable taken as the basis. The variables economic growth and the situation of Taiwan in the Triangle are annual. Chinese participation in Taiwan's foreign trade is observed monthly.

Table 2: Estimates of the initial dichotomous logistic model

\begin{tabular}{l|cccc}
\hline Effects & Estimate & Standard Error & p-value & Decision \\
\hline Intercept & $-0,194$ & 0,473 & 0,681 & - \\
China Diplomacy - Hostile & 4,217 & 0,975 & $<0,001$ & Significant \\
Party - DPP & $-18,377$ & 1235,285 & 0,988 & Not significant \\
$\mathbf{1 9 9 2}$ Consensus - No & 18,695 & 1235,286 & 0,988 & Not significant \\
Electoral Period - No & $-0,936$ & 0,998 & 0,348 & Not significant \\
Economic growth & $-0,159$ & 0,357 & 0,656 & Not significant \\
Foreign trade & $-1,298$ & 0,411 & 0,002 & Significant \\
Triangle situation & 0,752 & 0,399 & 0,059 & Significant \\
\hline
\end{tabular}

Source: Elaborated by the author.

The initial model indicates that, at 5\% significance level, Chinese diplomatic action and Chinese participation in Taiwan's foreign trade are the significant variables in the model. When considering the $10 \%$ significance level, the Taiwanese situation in the Triangle is added to these variables.

Regarding the estimates and standard errors, the values obtained for the ruling party (DPP) and the 1992 Consensus are different from the others. The standard error of both estimates is extremely high, possibly indicating the existence of multicollinearity in the model.

Thus, when calculating the Variance Inflation Factor (VIF) for the model, a value greater than 10 was obtained for the Party and 1992 Consensus measure. That is, the variables in question are an almost perfect linear combination of each other and their joining in the same. model causes problems for parameter estimation.

Consequently, two models were derived from the initial model. In the first model only the effect of the ruling party was removed from the initial model and, in the second, only the 1992 consensus. As a criterion for choosing the most appropriate model, the Stepwise - Backward selection method was made for both cases.

After model selection, the model with the smallest AIC based on the first model is given by the equation below:

$$
\begin{aligned}
& \ln \left(\frac{\hat{g}(\mathbf{x})}{1-\hat{g}(\mathbf{x})}\right)=-0.231+3.585 \text { Conflicting Diploma }-1.827 \text { Electoral Period } \\
& -0.7323 \text { Foreign trade }+0.911 \text { Triangle situation }+0.852 \text { Consensus }
\end{aligned}
$$

Now the model with smaller AIC based on the second model is given by:

$$
\begin{gathered}
\ln \left(\frac{\hat{g}(\mathbf{x})}{1-\hat{g}(\mathbf{x})}\right)=0.027+3.972 \text { Conflicting Diffomacy }-1.834 \text { Electoral Period } \\
-0,764-0.764 \text { Foreign trade }+1,099 \text { Triangle situation }
\end{gathered}
$$

The difference between the models lies in the fact that the 1992 Consensus variable was included in the model of equation (1). The AIC of the equation (1) model equals 150.92 and 
equation (2), 151.07. As the difference between the AIC is very small, the Maximum Likelihood Ratio Test was performed and returned p-value 0.1423, indicating that there is no evidence for rejecting the null hypothesis. Thus, we adopt the simplest model, that is, the model of equation (2) as a candidate for the final model. The table 3 shows the results of equation (2).

Table 3: Estimates of the Dichotomous Logistic Model of the Equation (2)

\begin{tabular}{l|llll}
\hline Effects & Estimate & Standard Error & p-value & Decision \\
\hline Intercept & 0,027 & 0,373 & 0,942 & - \\
China Diplomacy - Hostile & 3,972 & 0,858 & $<0,001$ & Significant \\
Electoral Period - No & $-1,834$ & 0,774 & 0,018 & Significant \\
Foreign trade & $-0,764$ & 0,321 & 0,017 & Significant \\
Triangle situation & 1,099 & 0,281 & $<0,001$ & Significant \\
\hline \multicolumn{2}{r}{}
\end{tabular}

The VIF was calculated for the new model. All values obtained are below 2, which indicates no multicollinearity problems. Moreover, this same model was compared through the Likelihood Ratio Test with the model that has an interaction parameter between continuous variables. However, there was no evidence to reject the hypothesis that the simplest model fits the data well.

All variables included in the model presented in Table 3 are significant at the 5\% significance level. As standard errors are low, there is no evidence of inconsistent estimates. To check the overall quality of adjustment the Hosmer and Lemeshow Test was applied. The test statistic returned p-value equal to 0.071 providing evidence that, at the $5 \%$ significance level, the proposed model can explain well what is observed.

Hence, the final model for dichotomous logistic regression is given by equation (2). The odds ratios for the variables are presented in the table 4 below:

Table 4: Estimated odds ratios for the dichotomous logistic model variables of the equation (2)

\begin{tabular}{l|c}
\hline \multicolumn{1}{c|}{ Effects } & $\widehat{\text { OR }}$ \\
\hline China Diplomacy - Hostile & $\exp (3,972) \cong 53,10$ \\
Electoral Period - No & $\exp (-1,834) \cong 0,16$ \\
Foreign trade & $\exp (-0,764) \cong 0,47$ \\
Triangle situation & $\exp (1,099) \cong 3,00$ \\
\hline
\end{tabular}

Source: Elaborated by the author.

So, based on Table 4, remaining constant all other variable, the chance that the Taiwan's diplomatic action being hostile when Chinese diplomacy is also conflicting is approximately 53.10 times higher than the chance of Taiwanese action being hostile when the Chinese attitude is cooperative. Given that the sign of the estimate is positive, the probability of Chinese diplomatic action being hostile is greater than the probability of cooperative diplomatic action.

The president Lee Teng-hui and Chen Shui-bian change dramatically their Cross-Strait policies during their administrations because of constant China hostile movements. Ma Ying-jeou on the other hand had better relations with China, the reason were the acceptance of 1992 Consensus (CHEN, 2009). The table 5 illustrates the presidents Cross-Strait policy per year, we can observe that during the Lee and Chen administrations there were big adjustments on Taiwanese China's Policy. 
Table 5: Taiwan Cross-Strait Policy, 1996-2016

\begin{tabular}{|l|l|}
\hline Year & \multicolumn{1}{|c|}{ Policy } \\
\hline 1996 & Status quo - future conditional unification \\
\hline 1997 & Status quo - future conditional unification \\
\hline 1998 & Status quo - future conditional unification \\
\hline 1999 & State-to-State Theory \\
\hline 2000 & Status quo - Do not propose unification, or accept the "One China" policy \\
\hline 2001 & Status quo - Do not propose unification, or accept the "One China" policy \\
\hline 2002 & Status quo - Do not propose unification, or accept the "One China" policy \\
\hline 2003 & One country on each side of the strait \\
\hline 2005 & One country on each side of the strait \\
\hline 2006 & One country on each side of the strait \\
\hline 2007 & One country on each side of the strait \\
\hline 2008 & Status Quo - Accept the "One China"policy \\
\hline 2009 & Status Quo - Accept the "One China"policy \\
\hline 2010 & Status Quo - Accept the "One China"policy \\
\hline 2011 & Status Quo - Accept the "One China"policy \\
\hline 2012 & Status Quo - Accept the "One China"policy \\
\hline 2013 & Status Quo - Accept the "One China"policy \\
\hline 2014 & Status Quo - Accept the "One China"policy \\
\hline 2015 & Status Quo - Accept the "One China"policy \\
\hline 2016 & Status quo - Do not propose unification, or accept the "One China" policy \\
\hline 2017 & Status quo - Do not propose unification, or accept the "One China" policy \\
\hline 2018 & Status quo - Do not propose unification, or accept the "One China" policy \\
\hline 2019 & Status quo - Do not propose unification, or accept the "One China" policy \\
\hline & \\
\hline
\end{tabular}

Both Lee Teng-hui and Chen Shui-bian started their presidency with a proposal of cooperative Strait Policy, not challenge the status quo and improve the economical, logistical and social integration. President Lee suggested in his inaugural speech a propensity to discuss future unification with Mainland China under four conditions: 1) The Chinese government respect the reality that the Republic of China in Taiwan de facto exist; 2) Guarantee Taiwan security; 3) The two side coexist in the international organizations; 4) China renounce the use of force. The inaugural speech was clearly a discourse pro status quo. In 1999, after constants movements from China pressing for political talks to settle an agenda for unification and the United States supporting these negotiations, president Lee and his diplomatic advisers decided to declare the State to State Policy (LING, 2011).

Chen Shui-bian political party do not support the "One China" framework, the initial Chen's China Policy was marked by the proposal of no independence, no change on national titles, no State-to-State theory, no referendum, if the Chinese Communist Party didn't use the force against Taiwan (Four Noes Policy). The principles corresponded a conciliation approach showing goodwill, active cooperation, and permanent peace. Although the conciliator ton of Chen administration, the Chinese government had fail to renounce hostile activities against Taiwan, for this reason Chen and his diplomacy decided that the Four Noes Policy could be abandoned (BULLARD, 2008). And, it indeed happened. The previous policy was replace by the "Four Yes and One No Policy": yes to independence; yes to new Constitution; yes to change the name of the country from Republic of China to Republic of Taiwan; yes to economic development; and to the use of force against Taiwan (LING, 2011).

The second regression result is the electoral period, the chance of Taiwan's diplomatic action being hostile when it is not in the election period is approximately 0.16 times less than the chance of action being hostile when it is in the election period. 
The democratic period in Taiwan demonstrated an inclination of the two principals political parties in Taiwan, Kuomintang (KMT) and Democratic Progressive Party (DPP), to present more moderate Cross-Strait policy proposition, not immediate unification or independence. At first, the ideological compromise helps to create loyalty inside the society, for instance, the KMT since 1949 proposed the unification of China and Taiwan territory, the Mainland is believed govern by an illegal political party, the Chinese Communist Party. The DPP, on the other hand, from the time when new parties were allowed, in the 1980's, planned the independence of Taiwan (WU, 2005). The chart 1 demonstrates the constituency preference on Cross-Strait Policy from 1996 to 2015.

Chart 1: Public opinion on Taiwan Cross-Strait Policy

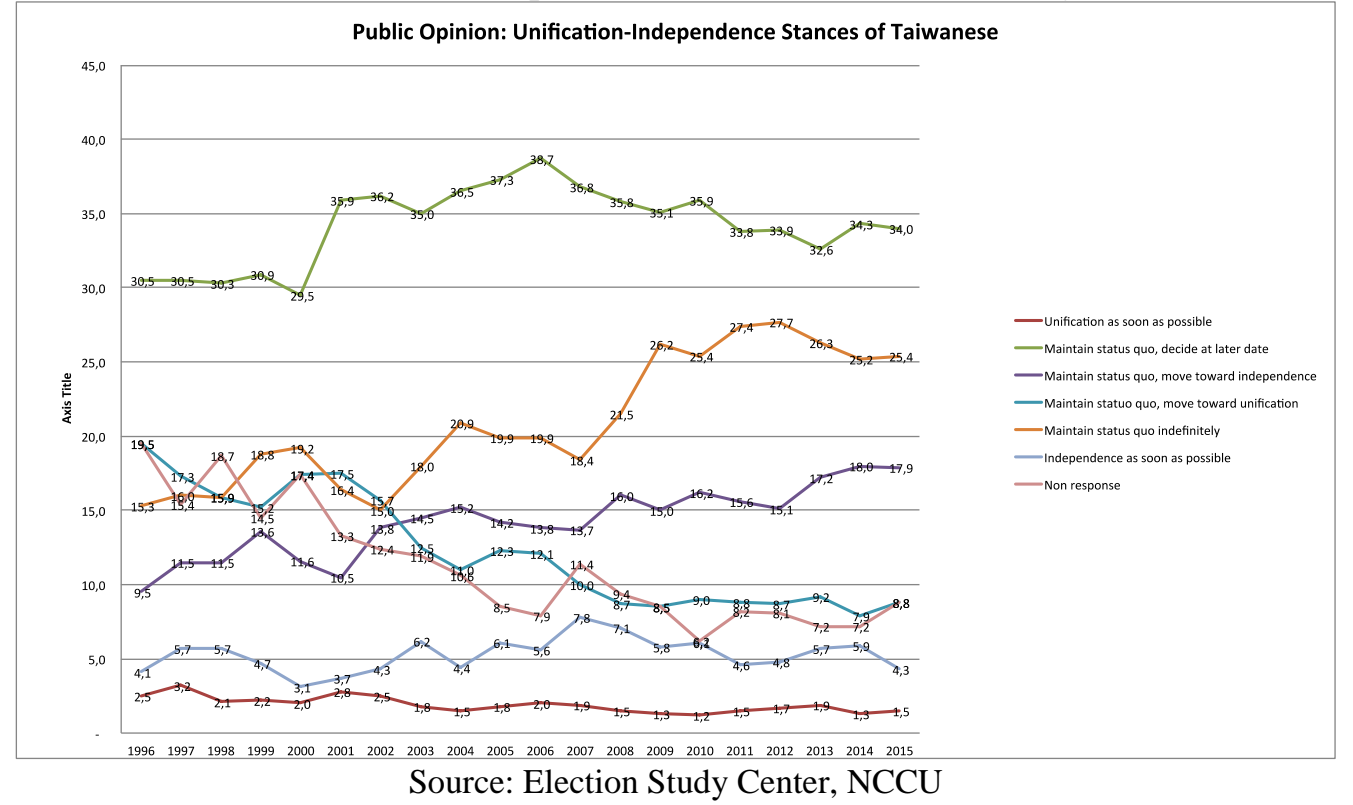

The status quo is the most desire policy by the constituency. It's possible to observe that maintain the status quo variance reach in 2015 the percentage of $77.3 \%$. The Independence or unification as soon as possible corresponds to only 5,8\% of the Taiwanese electorate in the last year of the poll, the Taiwan population request moderation of diplomatic authorities. The parties are aware of this trend, during elections the main political parties most of the time present a China Policy closer to status quo. In table 6 we summarized the idealistic point of each political party Cross-Strait policy and what they understand is the status through the strait.

Table 6: Taiwanese Political Party Cross-Strait Policy

\begin{tabular}{|l|l|l|}
\hline $\begin{array}{l}\text { Characterization of } \\
\text { Status quo }\end{array}$ & $\begin{array}{l}\text { The Republic of China has sovereignty over Mainland } \\
\text { and Taiwan, but the actual jurisdiction is only on Taiwan. }\end{array}$ & $\begin{array}{l}\text { Taiwan is an independent nation, don't need to } \\
\text { declare. }\end{array}$ \\
\hline $\begin{array}{l}\text { Future of Nation } \\
\text { Preference }\end{array}$ & Gradual and conditional unification. & Independence. \\
\hline
\end{tabular}

Source: WU (2011)

The need to maximize the electoral support obligate the parties, since the elections in the 1990 's, to offered Cross-Strait policy closer to the triad "no unification, no independence, and no use of force". The parties also had to deal with the increase in importance of economics trades with China and its impacts on Taiwanese economy. The KMT and blue camp defend the continuous expansion of economic trade with China. The DPP and the green camp, similarly, starts to defend the economic rapprochement to China, but in slow steps and precautions necessaries to the Taiwanese economy does not incur on excessive dependence of Chinese Economy (WU, 2005).

As the third result of regression shows, the Chinese participation in Taiwan's foreign trade correspond a point of pressure to the Taiwanese political behavior domestic and internationally. The increase of Chinese percentage share in Taiwan trade by one percent, decreases the chance of Taiwan's diplomatic action being hostile to China by $53 \%$. 
The strength of economic ties between Taiwan and China developed interactions in labor, academic, social, and tourist areas, requiring regulations that permit the economic cooperation between the two sides. The regulatory policy in times of great tensions, as the Lee and Chen governments, was implemented unilaterally, sometimes by Taiwan, sometimes by China (WU, 2005). During Ma's administration the two sides signed agreements to regulate this intense economic tie. The international trade corresponds to $70 \%$ of Taiwanese GDP, and $1 / 3$ of this amount descend from economic relations with China (DITTMER, 2012). Table 7 shows the Chinese participation in Taiwan Global Trade.

Table 7: China Participation in Taiwan Trade

\begin{tabular}{|c|c|c|}
\hline Year & Share $(\%)$ & Ranking \\
\hline 1996 & 1.68 & 14 \\
\hline 1997 & 1.92 & 12 \\
\hline 1998 & 2.29 & 11 \\
\hline 1999 & 3.04 & 7 \\
\hline 2000 & 3.63 & 6 \\
\hline 2001 & 4.60 & 4 \\
\hline 2002 & 7.44 & 4 \\
\hline 2003 & 12.17 & 3 \\
\hline 2004 & 15.13 & 2 \\
\hline 2005 & 16.72 & 1 \\
\hline 2006 & 17.94 & 1 \\
\hline 2007 & 19.40 & 1 \\
\hline 2008 & 19.81 & 1 \\
\hline 2009 & 20,81 & 1 \\
\hline 2010 & 21.46 & 1 \\
\hline 2011 & 21.63 & 1 \\
\hline 2012 & 21.27 & 1 \\
\hline 2013 & 21.61 & 1 \\
\hline 2014 & 22.14 & 1 \\
\hline 2015 & 22.67 & 1 \\
\hline 2016 & 22.54 & 1 \\
\hline 2017 & 24.23 & 1 \\
\hline 2018 & 24.28 & 1 \\
\hline 2019 & 23.87 & 1 \\
\hline
\end{tabular}

Source: Bureau of Foreign Trade

As we can see, since 2005 China represents the principal Taiwanese trade partner. The intensity of economics ties promotes the rise of political costs to the current Taiwanese president, Tsai Ing-wen, once she wants to change the scenario of Taiwan dependence on China economy.

The former president Ma Ying-jeou agreed with the Chinese leader Hu Jintao on five points plans, based on "1992 Consensus". They proposed a co-work between the CCP and KMT in opposing Taiwan independence and revive traditional Chinese culture in Taiwan (FELL, 2014). The five-points agreed were: First, the support to "1992 Consensus"; Second, the establishment of mechanisms for stable and peaceful cross-strait relations; Third, economic cooperation; Forth, negotiations on Taiwanese participation in international organizations; Fifth, party-to-party communication.

In the electoral campaign, the KMT candidate espouses the project to revitalizing the Taiwanese economy through the conciliation with China. The rapprochement between China and 
Taiwan proposed by the two parties into practice in 2008 when Ma won the presidential elections (WU, 2011). During his inaugural speech, Ma Ying-jeou declared:

I sincerely hope that the two sides of the Taiwan Strait can seize this historic opportunity to achieve peace and co prosperity. Under the principle of "no unification, no independence and no use of force", as Taiwan's mainstream public opinion holds it, and under the framework of the ROC Constitution, we will maintain the status quo in the Taiwan Strait. In 1992, the two sides reached a consensus on "one China, respective interpretations". Many rounds of negotiation were then completed, spurring the development of cross-strait relations. I want to reiterate that, based on the "1992 Consensus" negotiations should resume at the earliest time possible. As proposed in the Boao Forum on April 12 of this year, let's "face reality, pioneer a new future, shelve controversies and pursue a win-win solution".

In Ma's speech, the administration policy oppose to Taiwan independence, in addition accepted the 1992 consensus, and "One China" principle, allowing, during the eight years of Ma Ying-jeou presidency, better economic and political bilateral relations with China. As a result, the relationship with the United States improved, since Taipei diminished the U.S. concerns to balance the risks of war in the Taiwan Strait (WU, 2011).

At the $17^{\text {th }}$ Chinese Communist Party Congress, in 2007, was announced by the president $\mathrm{Hu}$ Jintao the adjustment in China approach toward Taiwan. This change in Chinese Taiwan Policy helped the Ma' administration in Cross-Strait rapprochement (SHULONG, 2014). The mainly priority shift of Chinese policy was the change in seeking early unification to preventing Taiwan independence. This modification resulted in a status quo tactic. According to the Hu Jintao policy, under the One-China principle the Chinese government proposed to promote the peaceful development between the two sides of the Taiwan Strait and prospect for the future a peaceful reunification (HUANG, 2011).

In this context of cooperation between the leaders of China and Taiwan, there was progress in Cross-Strait relations, amid 2008 and 2016 the Straits Exchange Foundation (SEF, 2018) and the Association for Relations Across the Taiwan Strait (ARATS) held eleven rounds of high-level talks, signed 23 agreements, issued two consensus and three common opinions and eleven Memorandum of Understanding (MoU). The principle applied most of the time by the two sides was easy issues first then difficult ones. So economic and financial spheres were prioritized in the bilateral relationship. On the other hand, political/security talks were unlikely. On 2009, for instance, Beijing tried to push for political agreements and Taipei refuse to go further, the main argument was that no consensus in Taiwan society about peace agreement, or even, a reunification process (ZHANG, 2013).

So, when Tsai Ing-Wen took office in May 2016, economic ties with China were not only strengthened but regulated. These make Taiwan vulnerable to instability in the Chinese economy as well as political pressures (SAUTIN, 2017). In fact, the Chinese Communist Party has intensified contacts with the Taiwanese business community to pressure them to take a stand position against possible Tsai moves away from China (CABESTAN, 2017).

Regarding the economic issue, during the administration of the Taiwanese new government, by the president Tsai Ing-Wen, the People's Republic of China has stopped buying agricultural and marine products from southern Taiwan, destroyed Taiwanese export products which pass through Chinese territory and did not adopt the name "Taiwan Area", and decreased issuing visas for tourists and students. These measures, however, had little impact on Taiwan's economy (FUKUDA, 2018; CHAN, 2018; YANG, 2018). As we can see in Table 8, even relatively low, in 2016, 2017 and 2018, Taiwan experienced economic growth despite China's stricter policy.

Table 8: Taiwan's economic growth (2015 to 2018)

\begin{tabular}{l|r|r|r|r}
\hline Year & 2015 & 2016 & 2017 & 2018 \\
\hline Economic Growth (\%) & 0,81 & 1,41 & 3,08 & 2,6 \\
\hline
\end{tabular}

Source: China Republic (2019) 
The fourth regression result was the position in strategic triangle. By increasing the indicator for the situation in the Triangle by one unit, the chance of Taiwanese diplomatic action being hostile is 3 times greater than the chance of Taiwanese diplomatic action being cooperative.

The situation in the Strategic Triangle becomes better to Taipei when Ma Ying-jeou wins the election in 2008 and implement a foreign policy that rapprochement toward China, economically and politically with the acceptance of "1992 consensus" and "One China" principle (CHEN, CHEN; WANG, 2013). The Ma administration also conquers a good relationship with United States. Taipei diminished the U.S. concerns to balance the risks of war in the Taiwan Strait (WU, 2011). Tsai Ing-wen wins the elections on 2016, in her inaugural speech she declared that the new government continuous have good economic relations with China and respect the agreement signed by the former administration. One point in the inaugural speech needs attention is the ambiguous statement about the "1992 consensus", Tsai was not clear if she accepts it or not. The Chinese leader Xi Jinping asked the United States to role as a pivot in Cross-Strait strategic triangle (BUSH III, 2015; BUSH III, 2016).

In the strategic triangle the role played by each country has a payoff. Payoff means that the weight of a nation in the Strategic Triangle is derived from its capabilities, military and economic, plus the interaction with the other player. Assumed that in the real-world superpower, as United States, rising power, as China, and mini states, as Taiwan are not in the same category of influence in the foreign affairs (WU, 2011).

As we are interested in the Taiwanese Cross-Strait policy lets calculate the Taiwan payoff in the strategic triangle, to do so we collect data regarding the GDP from the International Monetary Fund, and information about military expenditure from Stockholm International Peace Research Institute. The table 9 below demonstrates the Taiwanese payoff and the data, which originated it.

Table 9: D.C-Beijing-Taipei (GDP/Miliary Expenditure ${ }^{1}$ ) and Taiwan payoff factor in the Strategic Triangle

\begin{tabular}{|c|c|c|c|c|c|c|c|}
\hline Year & GDP u.s & GDP China & GDP taiwan & M u.s & M china & M taiwan & Ft \\
\hline 1996 & 8.100 .175 & 864.318 & 292.681 & 409.656 & 27.837 & 12.814 & 43,45251755 \\
\hline 1997 & 8.608 .525 & 961.892 & 303.706 & 407.537 & 29.858 & 12.760 & 10,94052878 \\
\hline 1998 & 9.089 .150 & 1.028 .808 & 280.407 & 398.332 & 32.715 & 11.936 & 11,63922635 \\
\hline 1999 & 9.660 .625 & 1.092 .587 & 304.174 & 399.314 & 39.800 & 11.915 & $-18,05151377$ \\
\hline 2000 & 10.284 .750 & 1.208 .846 & 331.407 & 414.768 & 43.230 & 10.474 & $-19,60208614$ \\
\hline 2001 & 10.621 .825 & 1.336 .923 & 300.223 & 418.135 & 52.179 & 10.284 & 54,64720508 \\
\hline 2002 & 10.977 .525 & 1.468 .864 & 308.883 & 469.486 & 60.642 & 9.946 & 12,54633393 \\
\hline 2003 & 11.510 .675 & 1.660 .709 & 318.364 & 534.351 & 65.496 & 9.851 & $-76,69806035$ \\
\hline 2004 & 12.274 .925 & 1.952 .645 & 348.407 & 582.400 & 72.415 & 9.868 & $-80,39511025$ \\
\hline 2005 & 13.093 .700 & 2.291 .454 & 375.787 & 610.176 & 79.809 & 9.494 & $-85,21279205$ \\
\hline 2006 & 13.855 .900 & 2.751 .924 & 388.547 & 619.653 & 92.586 & 9.108 & $-90,70701455$ \\
\hline 2007 & 14.477 .625 & 3.542 .560 & 408.221 & 635.921 & 103.716 & 9.638 & $-90,66372045$ \\
\hline 2008 & 14.718 .575 & 4.564 .951 & 417.038 & 682.967 & 113.527 & 9.814 & 31,84955264 \\
\hline 2009 & 14.418 .725 & 5.071 .456 & 392.106 & 737.747 & 137.401 & 10.570 & 33,12546683 \\
\hline 2010 & 14.964 .400 & 6.005 .249 & 446.141 & 757.992 & 144.383 & 9.990 & 102,9975889 \\
\hline 2011 & 15.517 .925 & 7.442 .032 & 485.671 & 748.646 & 155.898 & 10.085 & 34,24168264 \\
\hline 2012 & 16.155 .250 & 8.471 .357 & 495.919 & 706.082 & 169.321 & 10.440 & 33,37734724 \\
\hline 2013 & 16.663 .150 & 9.518 .582 & 511.599 & 650.081 & 182.930 & 9.860 & 33,91503774 \\
\hline 2014 & 17.348 .075 & 10.430 .712 & 530.038 & 609.914 & 199.651 & 10.240 & 32,86703252 \\
\hline 2015 & 17.947 .000 & 10.982 .829 & 523.581 & 595.472 & 214.485 & 10.310 & 33,45352726 \\
\hline 2016 & 18.558 .129 & 11.383 .033 & 508.849 & 596.024 & 214.787 & 9.803 & 17,75238009 \\
\hline
\end{tabular}

Source: International Monetary Fund (2016); Stockholm International Peace Research Institute (2016).

${ }^{1}$ The Militaries expenditures are in 2014 constant dollars

${ }^{2}$ The 2016 GDP amounts are estimations based on IMF predictions and the 2016 Military expenditures based on SIPRI estimations 
If Taiwan does not have the U.S. military protection, China may use the force to accomplish unification. So, the Taiwanese Cross-Strait policy needs to take into account its payoff in the strategic triangle. The chart 2 shows the dynamics of Taiwanese payoff inside the strategic triangle.

Chart 2: Taiwan Factor on Strategic Triangle

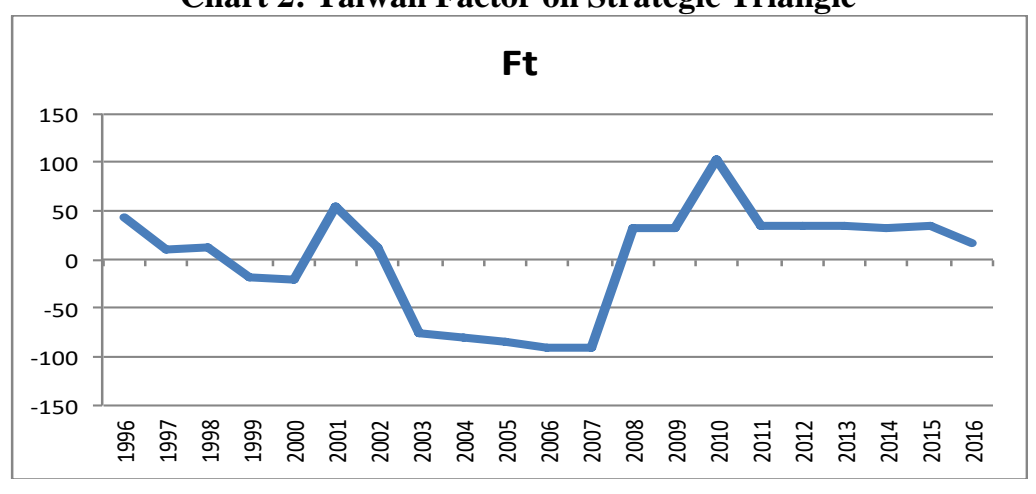

Source: International Monetary Fund (2016); Stockholm International Peace Research Institute (2016).

We can observe from the chart 2 that be an outcast in the strategic triangle is the worst role Taiwan can play, because it does not has the military capacity to defend itself and the United States may not perform the balance of power between Taiwan and China in a possible use of force. During five years of Chen Shui-bian administration, Taiwan experienced that position. The American diplomacy, the president himself and the Secretary of State, stated not support for Taiwan independence and movement made by the Taiwanese government (HUANG, 2011). Without the American support, Taiwan foreign policy was weakened. The best position for Taiwan was in Ma Ying-jeou when the administration has good relation both with China and United States.

\section{CONCLUSION}

China became the Taiwanese major trade partner since 2005. These represents the accomplishment of Chinese strategy to make Taiwan economically dependent and hence do not pursue political paths that move away the long Chinese dream and objective to finally incorporate Taiwanese territory to its own.

As shown by the regression analysis if China keeps pressure the Taiwanese government by hostile actions is more likely that the response will not be in the direction the Chinese may wanted to be. The most likely answer will be movements closer to declare the independence, even to Taiwanese authorities knowing that they are military weaker comparing to Chinese forces.

More difficult than convince any leader in Taiwan, China needs to reduce the Taiwanese people reluctance to unification. Maintain status quo is the preference of more than $77 \%$ of the population. Only economic actions will not change the perception that unification with mainland is a problematic issue. Political parties in Taiwan are aware of these trends and adopt most of the time status quo proposals to foreign policies during electoral periods. Just DPP, when Chen was the present and assume a more hostile attitude toward China in electoral period. He won the elections, but for a very tiny marge.

Now a days, because of economic ties between Taiwan and China a number of regulations between the two political entities are operational. Rules to control labor, academic, social and tourist issues were developed during the 20 years of the analysis. The Taiwanese administrations implemented some policies unilaterally, when the relations were conflictive, and during Ma's administration the sides signed 23 agreements to normalize the intense economic and social ties. A caution Taiwan needs is not to be vulnerable to every Chinese economic instability, alternatives must be made. 
The alternatives to Taiwan will depend on the situation in the Strategic Triangle with China and United States. How strong these two countries are inside the triangle helps or not Taiwan look for new partnerships in Asia and worldwide. A question remains for future studies in the field: There is space for an alternative future for Taiwan than the unification offers by Mainland China? The answer is difficult to provide, we have to look to the international, regional, U.S. Asia Policy, Cross-Strait relations and nationals conjectures.

\section{REFERENCES}

BULlaRD, M. R. The Cross-Strait Crisis: the case for optimism. Journal of Contemporary China, v. 17, n. 54, p. 107-120, 2008.

BUSH III, Richard. The return of the Taiwan issue to U.S.-China relations. In: BROOKINGS SERIES ORDER FROM CHAOS: FOREIGN POLICY IN A TROUBLED WORLD, 2015.

BUSH III, Richard. Tsai's inauguration in Taiwan: It could have been worse. In: BROOKINGS SERIES ORDER FROM CHAOS: FOREIGN POLICY IN A TROUBLED WORLD, 2016.

BUZAN, Barry; WAEVER, Ole. Regions and Powers: The Structure of International Security. Cambridge University Press, 2003.

CABESTAN, Jean-Pierre. Beijing's Policy Towards President Tsai Ying-wen and the Future of Cross-Strait Relations. Journal of Diplomacy and International Relations. v.18, n.1, p.54-71, 2017.

CABESTAN, Jean-Pierre. Ma Ying-jeou's Mainland policy since 2012: Ha it hardened and why?. In: $10^{\text {th }}$ SYMPOSIUM ON "CHINA-EUROPE RELATIONS AND THE CROSS-STRAIT RELATIONS, Shanghai, China, 2831 July 2013.

CHAN, Tara Francis. China is destroying imports that say 'Made in Taiwan' as part of its massive political crackdown. Business Insider [online]. 17 January 2018. At https://www.businessinsider.com/china-destroying-taiwan-labelledimports-2018-1. Accessed on 20 December 2018.

CHEN, Chien-Kai. Explaining the difference between Jiang Zemin's and Hu Jintao's attitudes towards the Taiwan issue. In: THE 2009 ANNUAL MEETING OF NORTHEASTERN POLITICAL SCIENCE ASSOCIATION, 2009.

CHEN, Lu-huei; CHEN, Ying-nan; WANG, T.Y. Interest, identity, and people's preference on the independence issue in Taiwan. In: HU, Weixing. New Dynamics in Cross-Taiwan Strait Relations: How far can the rapprochement go?. Routledge Editor, 2013.

CHRISTENSEN, Thomas. Taiwan's Legislative Yuan elections and Cross-Strait Security Relations: Reduced tensions and remaining challenges, China Leadership Monitor, n.13, 2006.

CLARK, Cal. The changing dynamics of relations among China, Taiwan, and the United States. In: CLARK, Cal. The changing dynamics of relations among China, Taiwan, and the United States. Cambridge Scholars Publishing, 2011.

DITTMER, Lowell. Analyzing the Taiwan Strait Triangle. In: Wu, Yu-shan. Revisiting Theories on Cross-Strait Relations. Taipei: IPSAS \& Wu Nan Publisher, 2012.

DITTMER, Lowell. The strategic triangle: An elementary game-theoretical analysis. World politics, v. 33, n. 4, p. 485$515,1981$.

DITTMER, Lowell. Washington between Beijing and Taipei: A Triangular Analysis. In: CLARK, Cal. The Changing Dynamics of Relations among China, Taiwan and the United States. Cambridge Scholars Publishing, 2011.

DREYER, June Teufel. The Japan-Taiwan Relationship: An Unstable Stability. Asia Policy, v. 26, n. 1, p. 161-166, 2019.

DUCHÂTEL, Mathieu. Between hedging and bandwagoning for profit: Taiwan's Mainland policy under Ma Ying-jeou. In: TRACK TWO DIALOGUE ON EU-CHINA RELATIONS AND THE TAIWAN QUESTION, Shanghai, China, 56 June 2010.

FELL, Dafydd. Taiwan's party system in the Ma Ying-jeou Era. In Jean-Pierre Cabestan and Jacques deLisle. Political Changes in Taiwan under Ma Ying-jeou: Partisan conflict, policy choices, external constrains and security challenges. Routledge Publish, 2014. 
FUKUDA, Madoka. The Current Situation and Prospects for Taiwan under the Tsai Ing-wen Administration. In: JAPANESE VIEWS ON CHINA AND TAIWAN: IMPLICATIONS FOR U.S - JAPAN ALLIANCE. Washington DC, 2018.

GEORGE, Alexander; BENNETT, Andrew. Case Studies and Theory Development in the Social Sciences. Cambridge: MIT Press. 2005.

HASEGAWA, Masanori. Close Economic Exchange with a Threatening State: An Awkward Dilemma over China. Asian Security, v. 14, n. 2, p. 155-171, 2018.

HUANG, Jing. Hu Jintao's pro-status quo approach in Cross-Strait relations: Building up an One-China framework for eventual reunification. In: CLARK, Cal. The Changing Dynamics of Relations among China, Taiwan and the United States. Cambridge Scholars Publishing, 2011.

HUANG, Min-hua. Taiwan's Changing Political Landscape: The KMT's Landslide Defeat in the Nine-in-One Elections. Brookings East Asia Commentary, December 2014.

LIN, Gang. Beijing's new strategies toward a changing Taiwan. Journal of Contemporary China, v. 25, n.99, 2016.

LING, Neng-Shan. Lee Teng-hui’s “Two-State” Theory: Perceptions and Policy Change. Soochow Journal of Political Science, v. 29, n.4, 2011.

SAUTIN, Yevgen. Cross-Strait relations under Trump: A view from Taiwan. European Council on Foreign Relations, 2017. At https://www.ecfr.eu/page/-/China_Analysis_Taiwan_Between_Xi_and_Trump.pdf. Accessed on 8 August 2018.

SHULONG, Chu, Mainland China's peaceful development strategy and Cross-Strait relations. In: CABESTAN, JeanPierre; DELISLE, Jacques. Political Changes in Taiwan under Ma Ying-jeou: Partisan conflict, policy choices, external constrains and security challenges. Ed: Routledge, 2014.

STEFF, Reuben; DODD-PARR, Francesca. Examining the immanent dilemma of small states in the Asia-Pacific: the strategic triangle between New Zealand, the US and China. The Pacific Review, v. 32, n.1, p.90-112, 2019.

SEF. Negotiate Agreements. Straits Exchange Foundation. http://www.sef.org.tw/lp.asp?ctNode=4384\&CtUnit=2569\&BaseDSD=7\&mp=300. Access on: 23 May 2018.

SZABO, Stephen F. Different Approaches to Russia: The German-American-Russian Strategic Triangle. German Politics, v. 27, n. 2, p. 230-243, 2018.

WEI, Yung. From functional integration to structural readjustment: Taipei-Beijing relations and the role of the United States. Journal of Contemporary China, v. 13, n. 40, p. 427-460, 2004.

WORMACK, Brandly; Wu, Yu-shan. Asymmetric Triangules and the Washington-Beijing-Taipei Relationship. In: WOMACK, Brantly. China among Unequals: Asymmetric Foreign Relations in Asia. Singapore: World Scientific Press, 2010.

WU, Yung; WU, Yenchun; WU, Shiann. Development and challenges of social enterprises in Taiwan-From the perspective of community development. Sustainability, v. 10, n. 6, p. 1797, 2018.

WU, Yu-shan. Revisiting Theories on Cross-Strait Relations. Taipei: IPSAS \& Wu Nan Publisher, 2012.

WU, Yu-Shan. Strategic Triangle, Change of Guard, and Ma's New Course. In: CLARK, Cal (ed). The changing dynamics of the relations among China, Taiwan, and the United States. Newcastle: Cambridge Scholars Publishing, p. 30-62, 2011.

WU, Yu-Shan. Taiwan's Domestic Policy and Cross-Strait Relations. The China Journal, n.53, p.35-60, 2005.

YANG, Alan H.; CHIANG, Jeremy HC. Enabling Human Values in Foreign Policy: The Transformation of Taiwan's New Southbound Policy. Journal of Human Values, v. 25, n. 2, p. 75-86, 2019.

YANG, Willian. Is Taiwan's tourism industry too reliant on China?' DW [online]. 15 May 2018. At https://www.dw.com/en/is-taiwans-tourism-industry-too-reliant-on-china/a-43777448, 2018.

ZHANG, Baohui. Peaceful unification vs. divided rule: Assessing political relations across the Taiwan Strait. In: HU, Weixing. New Dynamics in Cross-Strait Taiwan Relations: How far can the rapprochement go?, Routledge Editor, 2013. 
All authors stated that they had: a) actively participated in the discussion of the results; and b) Review and approval of the final version of the paper.

This work is licensed under a Creative Commons Attribution 4.0 International License. CC-BY 